\title{
POTENSI CADANGAN KARBON PADA LAHAN REHABILITASI DI KABUPATEN GUNUNG MAS, KALIMANTAN TENGAH
}

\section{(Carbon Stock Potential in Rehabilitation Land at Gunung Mas District, Central Kalimantan)}

\author{
RIA ASTUTI ${ }^{1 *)}$, BASUKI WASIS ${ }^{2)}$ DAN IWAN HILWAN ${ }^{2)}$ \\ 1) Program Studi Silvikultur Tropika, Fakultas Kehutanan, Jalan Lingkar Akademik Kampus IPB Dramaga, Bogor \\ 16680, Indonesia \\ 2) Departemen Silvikultur, Fakultas Kehutanan, Jalan Lingkar Akademik Kampus IPB Dramaga, Bogor 16680, \\ Indonesia
}

*Email: riariaria.astuti@gmail.com

Diterima 13 Februari 2020 / Disetujui 17 Juni 2020

\begin{abstract}
Global warming is one of the most serious problems for the environment. Forest rehabilitation can be done as an attempt to absorb carbon emissions. This study aims to determine the amount of biomass, casbon stock and $\mathrm{CO}_{2}$ sequestration before and after rehabilitation using non destructive methode. This research was conducted in five land covers (rehabilitation land 2015, 2016, 2017, open land and secondary forest) in three districts (Manuhing, Rungan Barat and Manuhing Raya) at Gunung Mas, Central Kalimantan. The highest above ground biomass of rehabilitation land both in 2015 and 2016 was at district Manuhing Raya whereas in 2017 the highest was in district Manuhing, this results could occur because of the additional input of natural fertilizer at this location resulting increase of soil fertility and better plant growth. Total biomass of the different land cover at Gunung Mas decreased in the order: secondary forest (483,19-823,49 ton/ha) > restoration land (2,04-84,96 ton/ha) > open land (0,02-0,12 ton/ha). Forest carbon stocks in Gunung Mas decreased drastically from 310,24-418,62 ton C/ha to 7,25-29,43 ton C/ha because of deforestation and forest conversions. Forest rehabilitation could increase land ability to absorb and deposit carbon stocks sustainably.
\end{abstract}

Keywords: carbon stocks, open land, rehabilitation, restoration land, secondary forest

\section{ABSTRAK}

Pemanasan global maupun deforestasi merupakan salah satu permasalahan paling serius untuk lingkungan. Rehabilitasi hutan dapat dilakukan sebagai salah satu upaya penyerapan emisi karbon. Penelitian bertujuan untuk menentukan besaran biomassa, karbon serta penyerapan $\mathrm{CO}_{2}$ sebelum dan setelah rehabilitasi dengan metode non destruktif. Penelitian dilakukan pada lima tutupan lahan (lahan rehabilitasi 2015, 2016, 2017, lahan terbuka, dan hutan sekunder) di tiga kecamatan (Manuhing, Rungan Barat, dan Manuhing Raya) di Kabupaten Gunung Mas, Kalimantan Tengah. Kandungan biomassa di atas permukaan tanah pada lahan rehabilitasi tertinggi baik pada tahun tanam 2015 maupun 2016 terdapat di Kecamatan Manuhing Raya, sedangkan pada tahun 2017 di Kecamatan Manuhing, hasil tersebut terjadi karena adanya input tambahan berupa pupuk alami di lokasi tersebut sehingga meningkatkan kesuburan tanah dan menjadikan pertumbuhan tanaman lebih baik. Total biomassa pada beberapa tutupan lahan di Kabupaten Gunung Mas semakin menurun dengan urutan: hutan sekunder (465,12-806,48 ton/ha) > lahan rehabilitasi (0,77-84,89 ton/ha) > lahan terbuka (0,001-0,06 ton/ha). Simpanan karbon mengalami penurunan yang sangat drastis dari 310,24418,62 ton C/ha menjadi 7,25-29,43 ton C/ha karena deforestasi dan alih fungsi hutan. Kegiatan rehabilitasi mampu meningkatkan kembali kemampuan suatu lahan dalam menyerap dan menyimpan cadangan karbon secara berkelanjutan.

Kata kunci: cadangan karbon, hutan sekunder, lahan rehabilitasi, lahan terbuka, rehabilitasi

\section{PENDAHULUAN}

Pemanasan global yang diakibatkan oleh peningkatan kadar $\mathrm{CO}_{2}$ di atmosfer merupakan salah satu permasalahan paling serius untuk iklim global (Houghton et al. 1996). Emisi gas $\mathrm{CO}_{2}$ dan gas rumah kaca lainnya di atmosfer sebagai akibat dari aktivitas manusia menyebabkan ketidakseimbangan di bumi dan mengakibatkan peningkatan kebutuhan informasi tentang permasalahan karbon global (Pichs-Madruga et al. 2014). Peningkatan gas rumah kaca disebabkan oleh pembakaran bahan bakar fosil, dan deforestasi (kebakaran hutan, illegal logging, dan konversi hutan)
(Pichs-Madruga et al. 2014; Tosiani 2015). Salah satu wilayah yang paling sering mengalami kebakaran hutan adalah Kalimantan. Provinsi Kalimantan Tengah merupakan wilayah yang setiap tahunnya menyumbangkan $\mathrm{CO}_{2}$ ke atmosfer melalui peristiwa tersebut. Tahun 2014 terjadi peristiwa kebakaran hutan dan lahan besar di Palangkaraya yang menghanguskan 629,36 ha lahan hutan dan mengakibatkan Palangkaraya dikepung asap selama musim kemarau tersebut (Karana 2014).

Hutan berperan penting dalam mitigasi $\mathrm{CO}_{2}$ dengan cara menyerap dan menyimpannya dalam bentuk biomassa melalui proses fotosintesis. Selain itu, secara 
alami tumbuhan juga memberikan manfaat ekstra dengan melepaskan oksigen ke udara melalui proses yang sama, sehingga hutan bisa menjadi penyangga yang baik terhadap pencemaran udara. Peningkatan penyerapan karbondioksida pada lahan terdegradasi dapat dilakukan dengan cara meningkatkan pertumbuhan biomassa hutan misalnya dengan kegiatan rehabilitasi hutan. Menurut Kurdi (2008), satu hektar daun-daun hijau dapat menyerap $8 \mathrm{~kg} \mathrm{CO}_{2} / \mathrm{jam}$ atau $0,8 \mathrm{~g} / \mathrm{m}^{2} / \mathrm{jam}$, setara dengan $\mathrm{CO}_{2}$ yang dihembuskan manusia sebanyak 200 orang dalam waktu yang sama. Penelitian Junaedi (2007) menunjukkan bahwa satu hektar hutan lahan kering primer di Kalimantan Tengah dapat menyimpan 229,33 ton karbon.

Kapasitas penimbunan karbon suatu hutan sangat dipengaruhi oleh daur (umur), tipe, fungsi hutan, jenis dan tingkat pertumbuhan tanaman serta kualitas tapaknya. Pengukuran cadangan karbon dilakukan untuk mengetahui akumulasi karbon yang tersimpan pada lokasi tersebut, sehingga dapat diketahui kapasitas hutan tersebut dalam menyerap karbon serta seberapa besar perannya dalam menurunkan emisi gas rumah kaca salah satunya $\mathrm{CO}_{2}$. Oleh karena itu, penelitian mengenai potensi cadangan karbon pada lahan rehabilitasi di Kabupaten Gunung Mas, Kalimantan Tengah dilakukan dengan tujuan untuk menentukan biomassa bagian atas permukaan tanah sebelum dan setelah dilakukan rehabilitasi dengan metode non-destruktif. Selain itu, menentukan nilai bahan organik tanah serta menentukan simpanan karbon dan penyerapan karbondioksida di lokasi tersebut.

\section{METODE PENELITIAN}

Penelitian dilaksanakan dari bulan Juli 2018 hingga Maret 2019 di Kecamatan Manuhing, Kecamatan Manuhing Raya dan Kecamatan Rungan Barat, Kabupaten Gunung Mas, Kalimantan Tengah (Gambar 1 dan Tabel 1). Analisis biomassa pada tumbuhan bawah dan nekromassa dilakukan di Laboratorium Hasil Hutan, Fakultas Pertanian, Universitas Palangkaraya. Adapun analisis tanah dilakukan di Laboratorium Indonesian Centre for Biodiversity and Biotechnology, Bogor.

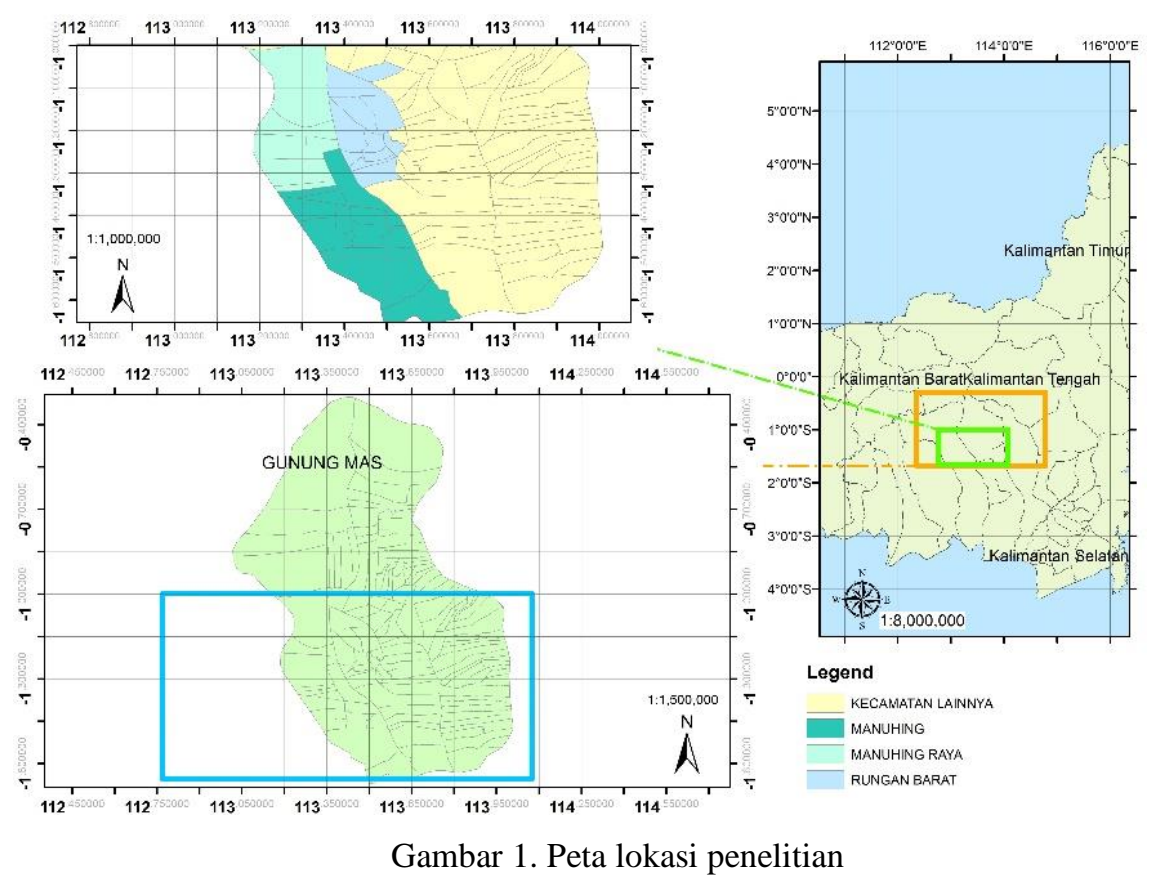

Tabel 1 Koordinat lokasi penelitian

\begin{tabular}{|c|c|c|c|}
\hline \multirow{2}{*}{$\begin{array}{l}\text { Tutupan lahan } \\
\text { Hutan sekunder }\end{array}$} & \multirow{2}{*}{$\begin{array}{l}\text { Lokasi } \\
\text { Manuhing }\end{array}$} & \multicolumn{2}{|c|}{ Koordinat geografis } \\
\hline & & $01^{\circ} 35^{\prime} 55.65^{\prime \prime} \mathrm{S}$ & $113^{\circ} 29^{\prime} 58.44^{\prime \prime} \mathrm{E}$ \\
\hline & Rungan Barat & $01^{\circ} 16^{\prime} 07.44^{\prime \prime} \mathrm{S}$ & $113^{\circ} 25^{\prime} 16.40^{\prime \prime} \mathrm{E}$ \\
\hline & Manuhing Raya & $01^{\circ} 07^{\prime} 30.96 " \mathrm{~S}$ & $113^{\circ} 16^{\prime} 55.31^{\prime \prime} \mathrm{E}$ \\
\hline \multirow{3}{*}{ Lahan terbuka } & Manuhing & $01^{\circ} 17^{\prime} 48.77^{\prime \prime} \mathrm{S}$ & $113^{\circ} 19^{\prime} 12.32^{\prime \prime} \mathrm{E}$ \\
\hline & Rungan Barat & $01^{\circ} 13^{\prime} 37.75^{\prime \prime} \mathrm{S}$ & $113^{\circ} 28^{\prime} 07.15^{\prime \prime} \mathrm{E}$ \\
\hline & Manuhing Raya & $01^{\circ} 21 ' 36.67^{\prime \prime} \mathrm{S}$ & $113^{\circ} 22^{\prime} 45.45^{\prime \prime} \mathrm{E}$ \\
\hline \multirow[t]{3}{*}{ Hutan sekunder } & Manuhing & $01^{\circ} 38^{\prime} 03.31^{\prime \prime} \mathrm{S}$ & $113^{\circ} 27^{\prime} 48.24^{\prime \prime} \mathrm{E}$ \\
\hline & Rungan Barat & $01^{\circ} 14 ’ 43.00 ” \mathrm{~S}$ & $113^{\circ} 22^{\prime} 18.47^{\prime \prime} \mathrm{E}$ \\
\hline & Manuhing Raya & $01^{\circ} 09^{\prime} 42.60 ” \mathrm{~S}$ & $113^{\circ} 13^{\prime} 59.28^{\prime \prime} \mathrm{E}$ \\
\hline
\end{tabular}


Alat dan bahan yang digunakan dalam penelitian ini adalah GPS (Global Positioning System), haga, kompas, meteran (panjang $50 \mathrm{~m}$ ), pita ukur, parang/golok, tali plastik, timbangan digital, plastik bening, kertas label, ring sampel, kantong plastik (1 dan $2 \mathrm{~kg}$ ), palu, papan, tongkat dbh 1,3 m, patok, plastic wrap, alumunium foil, alat tulis dan kamera. Adapun bahan yang digunakan adalah tally sheet, serasah, nekromassa, sampel tanah dan vegetasi hutan alam, hutan rakyat dan lahan terbuka di Kabupaten Gunung Mas.

Petak contoh yang digunakan dalam penelitian ini ditetapkan dengan metode purposive sampling dengan 5 plot contoh seperti pada Gambar 2 yang tersebar di 3 kecamatan dan 5 jenis tutupan lahan yaitu lahan rehabilitasi tahun tanam 2015, 2016, 2017, hutan sekunder dan lahan terbuka dengan total petak contoh sebanyak 75 unit. Penanaman lahan rehabilitasi tersebut dilakukan dengan sistem kerjasama dengan masyarakat sebagai pemilik lahan. Jenis tumbuhan yang ditanam adalah sengon sebagai jenis utama dan beberapa jenis lain seperti durian, cempedak dan ulin sesuai pilihan masyarakat. Hutan sekunder yang diamati pernah mengalami gangguan berupa pembalakan liar dengan intensitas ringan sehingga memiliki diameter pohon yang masih beragam dan mencapai $>30 \mathrm{~cm}$ pada tingkat pohon. Sedangkan, lahan terbuka yang diamati adalah lahan bekas penambangan liar masyarakat, kebakaran, dan lahan yang sengaja dibuka masyarakat untuk tujuan tertentu namun dibiarkan kosong begitu saja.

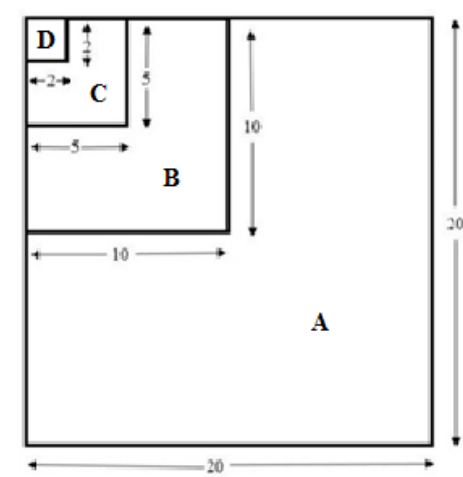

Gambar 2 Ilustrasi metode pengambilan data untuk analisis vegetasi. (A) Tingkat pohon, pohon mati dan kayu mati dilakukan pada petak ukur berukuran $20 \times 20 \mathrm{~m}$, (B) tingkat tiang pada petak ukur 10x10 m dan (C) tingkat pancang pada petak ukur $5 \times 5 \mathrm{~m}$ dengan metode non-destruktif, (D) Semai, tumbuhan bawah serta serasah diamati pada petak ukur $2 \times 2 \mathrm{~m}$ dengan metode destruktif (Rusolono et al. 2015)

Petak contoh yang digunakan adalah petak bersarang berbentuk persegi berukuran 20x20 m (Kusmana dan Istomo 1995; Laar dan Akca 1997; Soerianegara dan Indrawan 2005). Contoh tanah yang diamati adalah contoh tanah utuh dan contoh tanah terusik/terganggu untuk menguji sifat kimia dan sifat fisik tanah di areal pengamatan. Contoh tanah (pada tanah mineral) baik contoh tanah terganggu maupun utuh diambil pada tiga kedalaman yaitu $0-10 \mathrm{~cm}, 10-20 \mathrm{~cm}$, dan 20-30 cm (Wasis 2012).

Biomassa tumbuhan bawah dapat dihitung menggunakan persamaan BSN (2011):

Keterangan:

$$
B=\left(\frac{B K C}{B B C}\right) \times T B B
$$

B = Biomassa tumbuhan bawah $(\mathrm{kg})$

$\mathrm{BKC}=$ Berat kering contoh vegetasi $(\mathrm{kg})$

$\mathrm{BBC}=$ Berat basah contoh vegetasi $(\mathrm{kg})$

$\mathrm{TBB}=$ Total berat basah contoh vegetasi $(\mathrm{kg})$

Biomassa vegetasi dihitung menggunakan persamaan alometrik biomassa pohon (IPCC 2006):

$$
\mathrm{V}=\begin{aligned}
& \mathrm{B}=\mathrm{V} \times \mathrm{WD} \times \mathrm{BEF} \\
& 0.25 \pi \times\left(\frac{d}{100}\right)^{2} \times T \times f
\end{aligned}
$$

Keterangan:

$$
\begin{array}{ll}
\mathrm{B} & =\text { Biomassa pohon } \\
\mathrm{WD} & =\text { Kerapatan kayu } \\
\mathrm{BEF} & =\text { Biomassa Expansion Factor } \\
\mathrm{V} & =\text { Volume } \\
\mathrm{T} & =\text { Tinggi } \\
\mathrm{F} & =\text { Angka bentuk }
\end{array}
$$

Cadangan karbon pohon mati dihitung menggunakan persamaan BSN (2011):

$$
B_{p m}=0.25 \pi\left(\frac{D}{100}\right)^{2} \times T \times f \times W D_{p m}
$$

Keterangan:

$$
\begin{aligned}
& \mathrm{B}_{\mathrm{pm}} \quad=\text { Biomassa pohon mati }(\mathrm{kg}) \\
& \mathrm{B}_{\mathrm{p}} \quad=\text { Persamaan alometrik yang digunakan } \\
& \mathrm{D}=\text { Diameter pohon mati }(\mathrm{cm}) \\
& \mathrm{T}=\text { Tinggi pohon mati/tunggak }(\mathrm{m}) \\
& \mathrm{F}=\text { Faktor koreksi (kelas } 1=0,9 \text {, kelas } 2=0,8 \text {, } \\
& \text { kelas } 3=0,7 \text {, dan } 0,6 \text { jika tidak ada informasi } \\
& \text { untuk jenis tersebut) } \\
& B_{\mathrm{km}}=V_{\mathrm{km}} \times W D_{\mathrm{km}} \\
& V_{k m}=0.25 \pi \times\left(\frac{D p+D u}{200}\right)^{2} x P
\end{aligned}
$$

Keterangan:

$$
\begin{array}{ll}
\mathrm{Bkm} & =\text { Biomassa kayu mati }(\mathrm{kg}) \\
\mathrm{Vkm} & =\text { Volume kayu mati }\left(\mathrm{m}^{3}\right) \\
\mathrm{Dp} & =\text { Diameter pangkal }(\mathrm{cm}) \\
\mathrm{Du} & =\text { Diameter ujung }(\mathrm{cm}) \\
\mathrm{P} & =\text { Panjang kayu mati }(\mathrm{m})
\end{array}
$$

WDkm = Wood density atau kerapatan kayu mati $(\mathrm{kg} / \mathrm{m} 3)$

Biomassa serasah dapat dihitung menggunakan persamaan BSN (2011): 


$$
B_{S S}=\left(\frac{B K C_{S S}}{B B C_{S S}}\right) \times T B B_{S S}
$$

Keterangan:

Bss = Biomassa serasah $(\mathrm{kg})$

$\mathrm{BKC}_{\mathrm{SS}}=$ Berat kering contoh serasah $(\mathrm{kg})$

BBCss = Berat basah contoh serasah $(\mathrm{kg})$

TBBss = Total berat basah contoh serasah $(\mathrm{kg})$

Perhitungan karbon dari biomassa dan nekromassa menurut IPCC (2006):

Keterangan:

$$
C_{b}=B \times \% \text { C Organik }
$$

$\mathrm{C}_{\mathrm{b}}$

= Kandungan karbon biomassa /

nekromassa $(\mathrm{kg})$

B = Total biomassa / nekromassa $(\mathrm{kg})$

$\%$ C-Organik = Nilai persentase kandungan karbon yaitu sebesar 0,47

Menurut Rusolono et al. (2015) kandungan karbon tanah dihitung dengan menggunakan persamaan sebagai berikut:

$$
C_{t}=K_{t} \times B I_{t} \times \mathrm{Co}_{t}
$$

Keterangan:

$$
\begin{array}{ll}
\mathrm{C}_{\mathrm{t}} & =\text { Karbon tanah }\left(\mathrm{g} / \mathrm{cm}^{2}\right) \\
\mathrm{K}_{\mathrm{t}} & =\text { Kedalaman tanah }(\mathrm{cm}) \\
\mathrm{BI}_{\mathrm{t}} & =\text { Berat isi tanah }\left(\mathrm{g} / \mathrm{cm}^{3}\right) \\
\mathrm{Co}_{\mathrm{t}} & =\text { Kandungan C-organik tanah }(\%)
\end{array}
$$

Perhitungan serapan karbondioksida dihitung berdasarkan IPCC (2006):

$$
\mathrm{CO}_{2}=\mathrm{C} \times 3.67
$$

Keterangan:

$$
\begin{aligned}
\mathrm{CO}_{2}= & \text { Serapan karbondioksida (ton/ha) } \\
\mathrm{C}= & \text { Kandungan karbon dari carbon pool yang } \\
& \text { diamati (ton/ha). }
\end{aligned}
$$

\section{HASIL DAN PEMBAHASAN}

\section{Analisis Vegetasi di Lokasi Penelitian}

Area rehabilitasi di Kabupaten Gunung Mas Kalimantan Tengah merupakan lahan bekas kebakaran hutan, perladangan dan penambangan yang ditanam oleh masyarakat bekerjasama dengan LSM untuk tujuan meningkatkan kembali produktivitas tanah di lokasi tersebut. Jenis tanaman yang ditanam di lokasi tersebut adalah sengon (Paraserienthes falcataria). Jenis tersebut dipilih karena merupakan jenis kayu komersial yang cepat tumbuh serta pasarnya sudah banyak tersedia, sehingga hasil kayunya bisa dimanfaatkan oleh masyarakat dalam waktu yang relatif cepat dibanding jenis kayu lainnya. Tabel 1 menunjukkan nilai INP jenis pohon yang dominan pada beberapa tutupan lahan.

\section{Kandungan Biomassa di Atas Permukaan Tanah}

Diameter rata-rata tumbuhan yang ditanam di lokasi tersebut seperti terlihat pada Tabel 2. Biomassa atas permukaan di lokasi pengamatan sebagian besar didominasi oleh biomassa vegetasi yang terdiri dari pohon dan tumbuhan bawah. Biomassa nekromassa yang terdiri dari serasah, pohon mati dan kayu mati hanya menyumbang nilai yang sedikit seperti terlihat pada Tabel 2. Hal tersebut sesuai dengan pernyataan Olorunfemi et al. (2019) bahwa biomassa lebih banyak terdapat di atas permukaan dibandingkan dengan sumber lainnya. Besarnya biomassa nekromassa di Kecamatan Rungan Barat pada tahun penanaman 2017 lebih tinggi dibandingkan biomassa vegetasinya.

Berdasarkan Masripatin et al. (2010); Shunbao et al. (2019) perbedaan kandungan biomassa pada masingmasing kecamatan dan tahun tanam terjadi karena adanya perbedaan jenis tanaman dan kualitas lahannya. Lokasi tersebut semuanya memiliki jenis tanaman yang sama, sehingga yang mungkin menjadi perbedaan adalah kesuburan tanahnya. Namun, berdasarkan hasil analisis tanah pada Tabel 3 diketahui bahwa tingkat kesuburan tanah di lahan rehabilitasi Kabupaten Gunung Mas memiliki nilai yang hampir sama.

Tabel 1 Nilai INP jenis pohon yang dominan pada beberapa tutupan lahan

\begin{tabular}{lcccc}
\hline \multirow{2}{*}{ Nama jenis } & \multicolumn{4}{c}{ Indeks Nilai Penting (\%) } \\
\cline { 2 - 5 } & Hutan Rakyat & HS Manuhing & HS Rungan Barat & HS Manuhing Raya \\
\hline Sengon (Paraserienthes falcataria) & 300 & - & - & - \\
Meranti (Shorea sp.) & - & 29,663 & 37,019 & 22,022 \\
Gerunggang (Cratoxylon glaucum) & - & 17,021 & 18,096 & - \\
Tumih (Combretocarpus rotundatus) & - & - & - & 31,170 \\
Gemor (Alseodaphne pneumatophora) & - & - & - & 17,061 \\
Balangeran (Shorea balangeran) & - & 19,117 & 16,079 & - \\
\hline
\end{tabular}


Kandungan biomassa di atas permukaan tanah pada lahan rehabilitasi tertinggi baik pada tahun tanam 2015 maupun 2016 terdapat di Kecamatan Manuhing Raya dengan 84,96 ton/ha dan 29,31 ton/ha seperti pada Gambar 3. Berbeda dengan kandungan biomassa pada tahun tanam 2017 dimana Kecamatan Manuhing memiliki total biomassa atas permukaan tertinggi dengan 12,59 ton/ha (Gambar 3). Tahun penanaman $2017 \mathrm{di}$ Kecamatan Manuhing memiliki cadangan biomassa yang lebih besar dibandingkan biomassa tahun 2016 serta kedua kecamatan lainnya dengan tahun tanam yang sama. Hal tersebut terjadi karena adanya input tambahan berupa pupuk untuk meningkatkan kesuburan tanah di lahan penanaman tahun 2017 di Kecamatan Manuhing sehingga kandungan biomassanya lebih baik jika dibandingkan dengan lahan tahun tanam 2016 serta kedua kecamatan lainnya dengan tahun tanam yang sama. Kandungan biomassa juga sangat dipengaruhi oleh diameter batang, tinggi pohon, kerapatan dan berat jenis tumbuhan diatas lahan tersebut (Chairul et al. 2016; Behara et al. 2017; Urbano dan Keeton 2017).

Tabel 2 Kandungan biomassa di hutan rakyat Kabupaten Gunung Mas

\begin{tabular}{|c|c|c|c|c|c|c|c|c|c|c|}
\hline \multirow{2}{*}{ Tutupan lahan } & \multirow{2}{*}{ Lokasi } & \multirow{2}{*}{ Diameter rata-rata $(\mathrm{cm})$} & \multicolumn{5}{|c|}{ Biomassa (ton/ha) } & \multirow{2}{*}{$\mathrm{BH}$} & \multirow{2}{*}{$\mathrm{N}$} & \multirow{2}{*}{ ТВP } \\
\hline & & & Pohon & TB & Serasah & PM & KM & & & \\
\hline \multirow{3}{*}{ HR 2015} & Manuhing & $3-21$ & 21,9361 & 0,0427 & 0,0152 & 0,6621 & 0,1693 & 21,9788 & 0,8466 & 22,8254 \\
\hline & Rungan Barat & $10,7-21,6$ & 48,4215 & 0,0194 & 0,0298 & 0,5761 & 0,0003 & 48,4409 & 0,6062 & 49,0471 \\
\hline & Manuhing Raya & $10,3-17,1$ & 84,8574 & 0,0280 & 0,0466 & 0,0282 & 0 & 84,8854 & 0,0748 & 84,9602 \\
\hline \multirow{3}{*}{ HR 2016} & Manuhing & $3,3-6,9$ & 3,7594 & 0,0645 & 0,0173 & 0,1492 & 0 & 3,8239 & 0,1665 & 3,9904 \\
\hline & Rungan Barat & $6,1-9,8$ & 15,4714 & 0,0152 & 0,0322 & 3,2511 & 0,0005 & 15,4865 & 3,2838 & 18,7704 \\
\hline & Manuhing Raya & $6,7-9,2$ & 29,1938 & 0,0316 & 0,0204 & 0,0665 & 0,0002 & 29,2254 & 0,0871 & 29,3125 \\
\hline \multirow{3}{*}{ HR 2017} & Manuhing & $2,9-9,7$ & 11,7804 & 0,0143 & 0,0483 & 0,7461 & 0,0002 & 11,7947 & 0,7946 & 12,5893 \\
\hline & Rungan Barat & $1,7-3$ & 0,7588 & 0,0068 & 0,0225 & 0,9041 & 0,0008 & 0,7656 & 0,9273 & 1,6929 \\
\hline & Manuhing Raya & $1,4-6$ & 1,6574 & 0,0256 & 0,0183 & 0,3396 & 0,0004 & 1,6829 & 0,3583 & 2,0413 \\
\hline
\end{tabular}

Ket: HR: Hutan Rakyat, M: Manuhing, RB: Rungan Barat, MR: Manuhing Raya, SR: Sangat Rendah; TB: Tumbuhan Bawah, PM: Pohon Mati, KM: Kayu Mati, BH: Biomassa Hidup, N: Nekromassa, TBP: Total Biomassa Permukaan.

Tabel 3 Analisis sifat fisik dan kimia tanah pada berbagai tutupan lahan

\begin{tabular}{llllll}
\hline \multirow{2}{*}{ Parameter } & \multicolumn{3}{c}{ Lahan rehabilitasi } & \multirow{2}{*}{ Lahan terbuka } & Hutan sekunder \\
\cline { 2 - 4 } & \multicolumn{1}{c}{ Manuhing } & \multicolumn{1}{c}{ Rungan Barat } & Manuhing Raya & & $1,17 \pm 0,03$ \\
\hline Bulk density & $1,13 \pm 0,07$ & $1,13 \pm 0,06$ & $1,16 \pm 0,05$ & $1,14 \pm 0,05$ & $2,12 \pm 1,53$ \\
\hline Kadar air & $2,61 \pm 0,69$ & $1,49 \pm 0,66$ & $1,33 \pm 0,60$ & $1,14 \pm 0,75$ & $47,01 \pm 1,86(\mathrm{~KB})$ \\
\hline Porositas & $47,67 \pm 2,44(\mathrm{~KB})$ & $47,59 \pm 2,11(\mathrm{~KB})$ & $46,07 \pm 2,28(\mathrm{~KB})$ & $46,43 \pm 3,04(\mathrm{~KB})$ & $4,08 \pm 0,38(\mathrm{SM})$ \\
\hline pH KCl & $3,97 \pm 0,23(\mathrm{SM})$ & $3,95 \pm 0,12(\mathrm{SM})$ & $3,97 \pm 0,19(\mathrm{SM})$ & $3,91 \pm 0,22(\mathrm{SM})$ & 4,08 \\
\hline pH H2O & $5,21 \pm 0,28(\mathrm{M})$ & $5,06 \pm 0,33(\mathrm{M})$ & $5,44 \pm 0,24(\mathrm{M})$ & $5,65 \pm 0,56(\mathrm{M})$ & $5,32 \pm 0,72(\mathrm{M})$ \\
\hline KTK & $6,59 \pm 1,66(\mathrm{R})$ & $5,04 \pm 2,12(\mathrm{R})$ & $4,06 \pm 1,79(\mathrm{SR})$ & $2,91 \pm 1,78(\mathrm{SR})$ & $5,35 \pm 2,54(\mathrm{SR})$ \\
\hline C-Organik & $0,98 \pm 0,56(\mathrm{SR})$ & $0,99 \pm 0,82(\mathrm{SR})$ & $0,66 \pm 0,64(\mathrm{SR})$ & $0,68 \pm 0,72(\mathrm{SR})$ & $1,52 \pm 0,98(\mathrm{R})$ \\
\hline
\end{tabular}

Ket: KB: Kurang Baik, SM: Sangat Masam, M: Masam, R: Rendah, SR: Sangat Rendah.

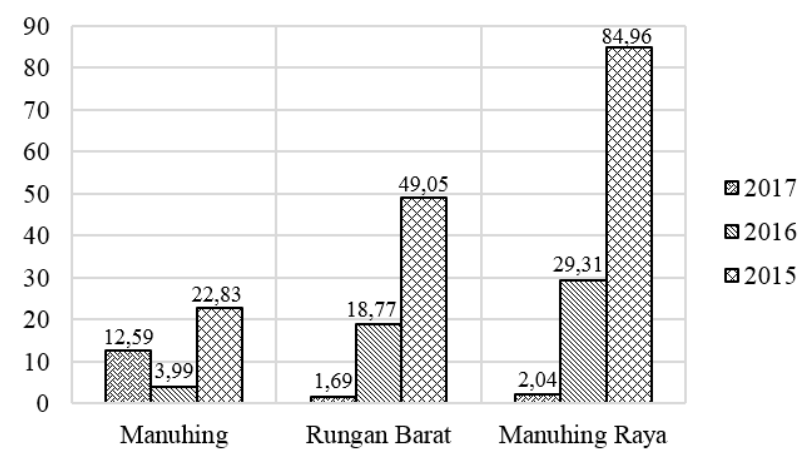

Gambar 3 Biomassa di atas permukaan di lahan rehabilitasi Kabupaten Gunung Mas 


\section{Kandungan Biomassa pada Berbagai Tutupan Lahan}

Ekosistem hutan merupakan bagian penting dari ekosistem daratan yang merupakan penyerap karbon global dan memiliki peran sebagai pencegah dampak pemanasan global dalam jangka waktu panjang dan berkelanjutan (Watson 2000; Pan et al. 2011; Birdsey dan Pan 2015; Nave et al. 2018). Hutan menyimpan $48 \%$ dari keseluruhan karbon di daratan (Watson et al. 2000; IPCC 2001; Liu et al. 2014) yang memproduksi lebih dari separuh produksi karbon global (Pan et al. 2011).

Gambar 4 menunjukkan bahwa biomassa atas permukaan tertinggi ditemukan pada hutan sekunder (483,19-823,49 ton/ha), kemudian diikuti oleh lahan rehabilitasi $(2,04-84,96$ ton/ha) dan lahan terbuka $(0,02-$ 0,12 ton/ha). Penelitian Tomich et al. dalam Hairiah dan Rahayu (2007) memperlihatkan bahwa hutan memiliki cadangan karbon yang lebih besar jika dibandingkan dengan tata guna lahan lainnya (Hairiah dan Rahayu 2007; Olorunfemi et al. 2019). Hutan memiliki keragaman jenis pohon berumur panjang yang tinggi serta serasah yang banyak, oleh karena itu hutan merupakan gudang penyimpan karbon tertinggi. Alih fungsi hutan untuk peruntukan lain seperti lahan pertanian atau pemukiman mengakibatkan jumlah karbon tersimpan akan merosot (Hairiah dan Rahayu 2007; Oktavianto et al. 2015).

Alih fungsi lahan dan deforestasi dapat menurunkan kandungan karbon yang tersimpan di dalam hutan dan menjadikan meningkatnya kadar karbon di atmosfer, terutama jika dalam proses pelepasan karbonnya melalui proses pembakaran biomassa. Perubahan tata guna lahan dan konversi hutan merupakan sumber emisi $\mathrm{CO}_{2}$ yang menyumbangkan sekitar $1,7 \pm 0,6 \mathrm{Pg} \mathrm{C}$ per tahun (Watson et al. 2000). Lokasi lahan terbuka yang dianalisis merupakan lahan bekas kebakaran, kegiatan penambangan rakyat maupun lahan yang sengaja dibuka untuk tujuan tertentu namun ditinggalkan begitu saja karena tidak ada sumber daya untuk mengolahnya. Lahan tersebut hanya ditumbuhi oleh tumbuhan bawah yang didominasi oleh rumput, kelakai dan resam sehingga kandungan biomassanya sangatlah sedikit.

\section{Potensi Simpanan Karbon dan Serapan Karbondioksida}

Karbondiokasida dianggap sebagai GRK utama karena memiliki laju pertambahan emisi yang tinggi dan waktu tinggal di atmosfer yang lama (Junaedi 2007). Vegetasi memiliki peran penting dalam mitigasi karbondioksida dengan menyimpan cadangan karbon pada biomassa di atas permukaan dan kantong karbon (Pan et al. 2011; Birdsey dan Pan 2015; Nave et al. 2018). Hutan merupakan salah satu ekosistem di daratan dengan komposisi tumbuhan yang relatif dominan, sehingga hutan menjadi salah satu ekosistem yang paling dominan dalam menyerap karbondioksida. Akan tetapi dengan semakin meningkatnya laju deforestasi, penyerapan karbondioksida mengalami penurunan.

Tabel 4 menunjukkan potensi simpanan karbon pada beberapa tutupan lahan di Kabupaten Gunung Mas, Kalimantan Tengah. Cadangan karbon di hutan Kabupaten Gunung Mas berkisar antara 310,24-418,62 ton $\mathrm{C} /$ ha dan mengalami penurunan hingga 7,25-29,43 ton $\mathrm{C} /$ ha karena adanya alih deforestasi dan alih fungsi hutan. Hutan yang terdegradasi lambat laun akan kehilangan fungsinya sebagai penyerap karbon, bahkan akan menjadi sumber karbon jika proses disertai dengan proses pembakaran hutan. Berdasarkan penelitian Junaedi (2007) hutan lahan kering primer di Kalimantan Tengah mempunyai cadangan karbon sebesar 229,33 ton $\mathrm{C} /$ ha, sedangkan hutan bekas tebangan hanya sekitar 57,66-107,71 ton $\mathrm{C} /$ ha. Serapan karbondioksida pada hutan sekunder adalah 1.138,57-1.536,35 ton $\mathrm{CO}_{2}$ eq/ha sedangkan pada lahan terbuka adalah 26,60-107,99 ton $\mathrm{CO}_{2}$ eq/ha.

Kegiatan rehabilitasi mampu meningkatkan kembali kemampuan suatu lahan dalam menyerap dan menyimpan cadangan karbon secara berkala. Total serapan karbon pada lahan rehabilitasi tahun tanam 2017 adalah 45,94-51,55 ton $\mathrm{C} / \mathrm{ha}$, meningkat jika dibandingkan dengan lahan terbuka. Serapan karbon semakin meningkat pada tahun penanaman 2016 yakni 25,59-74,26 ton $\mathrm{C} /$ ha serta pada tahun penanaman 2015 sebesar 28,52-52,73 ton $\mathrm{C} /$ ha. Kemampuan penyerapan karbon pada lahan-lahan tersebut semakin meningkat melalui kegiatan rehabilitasi. Hasil tersebut masih jauh berbeda jika dibandingkan dengan kemampuan hutan dalam menyimpan karbon, terutama karena perbedaan komposisi jenis dan umur tanaman dari kedua jenis tutupan lahan tersebut. 


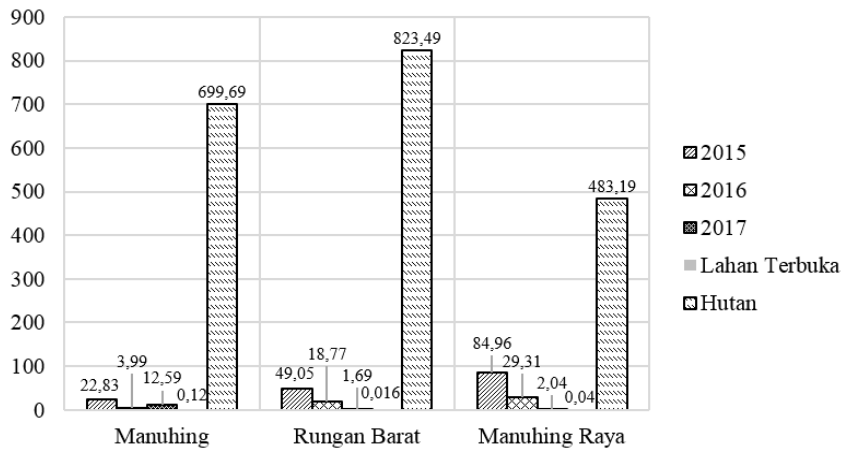

Gambar 4 Biomassa pada berbagai tutupan lahan di Kabupaten Gunung Mas

Tabel 4 Potensi simpanan karbon di Kabupaten Gunung Mas

\begin{tabular}{|c|c|c|c|c|c|}
\hline $\begin{array}{l}\text { Tutupan } \\
\text { lahan }\end{array}$ & Lokasi & $\begin{array}{c}\text { KPT } \\
\text { (ton } \mathrm{C} / \mathrm{ha} \text { ) }\end{array}$ & $\begin{array}{c}\text { KT } \\
\text { (ton } \mathrm{C} / \mathrm{ha} \text { ) }\end{array}$ & $\begin{array}{c}\mathrm{TK} \\
\text { (ton } \mathrm{C} / \mathrm{ha} \text { ) }\end{array}$ & $\begin{array}{c}\text { Serapan } \mathrm{CO}_{2} \text { (ton } \\
\mathrm{CO}_{2} \text { eq/ha) }\end{array}$ \\
\hline HR & $\mathrm{M}$ & 10,73 & 17,79 & 28,52 & 104,66 \\
\hline \multirow[t]{2}{*}{2015} & $\mathrm{RB}$ & 23,05 & 15,56 & 38,61 & 141,71 \\
\hline & MR & 39,93 & 12,79 & 52,73 & 193,50 \\
\hline HR & $\mathrm{M}$ & 1,88 & 23,72 & 25,59 & 93,919 \\
\hline \multirow[t]{2}{*}{2016} & $\mathrm{RB}$ & 8,82 & 65,44 & 74,26 & 272,55 \\
\hline & MR & 13,78 & 42,09 & 55,87 & 205,06 \\
\hline HR & $\mathrm{M}$ & 5,92 & 40,03 & 45,94 & 168,62 \\
\hline \multirow[t]{2}{*}{2017} & $\mathrm{RB}$ & 0,79 & 50,59 & 51,39 & 188,59 \\
\hline & MR & 0,96 & 50,59 & 51,55 & 189,19 \\
\hline \multirow[t]{3}{*}{$\mathrm{LT}$} & $\mathrm{M}$ & 0,06 & 29,37 & 29,43 & 107,99 \\
\hline & $\mathrm{RB}$ & 0,01 & 17,37 & 17,37 & 63,76 \\
\hline & MR & 0,02 & 7,23 & 7,25 & 26,60 \\
\hline \multirow[t]{3}{*}{ HS } & $\mathrm{M}$ & 328,85 & 42,38 & 371,23 & 1362,42 \\
\hline & $\mathrm{RB}$ & 387,04 & 31,58 & 418,623 & 1536,35 \\
\hline & MR & 227,09 & 83,14 & 310,24 & 1138,57 \\
\hline
\end{tabular}

Ket: M: Manuhing, RB: Rungan Barat, MR: Manuhing Raya, LT: Lahan terbuka, HS: Hutan sekunder, KPT: Karbon permukaan anah, KT: Karbon tanah, TK: Total karbon.

\section{SIMPULAN}

Kandungan biomassa di atas permukaan lahan rehabilitasi di Kabupaten Gunung Mas tertinggi baik pada tahun tanam 2015 maupun 2016 terdapat di Kecamatan Manuhing Raya dengan 84,96 ton/ha dan 29,31 ton/ha. Kandungan biomassa pada tahun tanam 2017 tertinggi terdapat di Kecamatan Manuhing dengan 12,59 ton/ha, hal tersebut mungkin terjadi karena adanya input tambahan berupa pupuk di lokasi tersebut sehingga meningkatkan kesuburan tanah dan menjadikan pertumbuhan tanaman lebih baik. Kandungan biomassa pada beberapa tutupan lahan di Kabupaten Gunung Mas semakin menurun dengan urutan: hutan sekunder $(483,19-823,49$ ton/ha) > lahan rehabilitasi $(2,04-84,96$ ton/ha) > lahan terbuka $(0,02-0,12$ ton/ha).
Simpanan karbon mengalami penurunan yang sangat drastis akibat deforestasi. Cadangan karbon di hutan Kabupaten Gunung Mas berkisar antara 310,24418,62 ton $\mathrm{C} /$ ha dan menurun hingga 7,25-29,43 ton $\mathrm{C} /$ ha karena adanya alih fungsi hutan. Kegiatan penanaman, mampu meningkatkan kembali kemampuan suatu lahan dalam menyerap dan menyimpan cadangan karbon secara berkala.

\section{DAFTAR PUSTAKA}

Behara SK, Sahu N, Mishra AK, Bargali SS, Behara MD, Tuli R. 2017. Aboveground biomassa and carbon stock assessment in Indian tropical deciduous 
forest and relationship whit stand atructure attributes. Ecological engineering. 99:513-524.

Birdsey R, Pan Y. 2015. Trends in management of the world's forests and impacts on carbon stocks. For. Ecol. Manag. 355:83-90. https://doi.org/10.1016/j.foreco.2015.04.031.

BSN [Badan Standarisasi Nasional]. 2011. SNI 7724:2011: Pengukuran dan Perhitungan Cadangan Karbon - Pengukuran Lapangan untuk Penaksiran Cadangan Karbon Hutan (Ground based Forest Carbon Accounting). Jakarta: Badan Standarisasi Nasional.

Chairul, Muchtar E, Mansyurdin, Tesri M, Indra G. 2016. Struktur kerapatan vegetasi dan estimasi kandungan karbon beberapa kondisi hutan di Pulau Siberut Sumatera Barat. Jurnal Metamorfosa. 3(1):15-22.

Hairiah, Rahayu. 2007. Pengukuran Karbon Tersimpan di Berbagai Macam Penggunaan Lahan. Bogor: World Agroforestry Centre - ICRAF, SEA Regional Office, University of Brawijaya, Indonesia.

Houghton JT, Meira FLG, Callander BA, Harris N, Kattenberg A, Maskell K. 1996. Climate change 1995: The Science of Climate Change-Technical Summary. Cambridge: Cambridge University Press.

[IPCC] Intergovernmental Panel on Climate Change. 2001. IPCC Third Assessment Report. Climate Change 2001: The Scientific Basis. Contribution of Working Group 1 to The Third Assessment Report of the Intergovernmental Panel on Climate Change. Cambridge dan New York: Cambridge University Press.

[IPCC] Intergovernmental Panel on Climate Change. 2006. IPCC Guidlines for National Greenhouse Gas Inventories. Jepang: Intergovernmental Panel on Climate Change.

Junaedi A. 2007. Dampak pemanenan kayu dan perlakuan silvikultur tebang pilih tanam jalur (TPTJ) terhadap potensi kandungan karbon dalam vegetasi hutan alam tropika (Studi kasus di areal IUPHHK PT Sari bumi kusuma, Kalimantan tengah) [tesis]. Bogor: Institut Pertanian Bogor.

Karana WW. 2014. Kebakaran hanguskan 629 hektare hutan kalteng. Tempo.co [Internet]. 9 September 2014; 14 Mei 2018: https://nasional.tempo.co/read/605417/kebakaranhanguskan-629-hektare-hutan-kalteng

Kurdi SZ. 2008. Pengaruh emisi CO2 dari sektor perumahan perkotaan terhadap kualitas lingkungan global. Jurnal Permukiman. 2(3):137-150.

Kusmana C, Istomo. 1995. Forest Ecology. Bogor: Faculty of Forestry.

Laar AV, Akca A. 1997. Forest Mensuration. Germany: Cuvillier Verlag Gotingen.

Liu XR, Ekoungoulou R, Loumeto JJ, Ifo SA, Bocko YE, Koula FE. 2014. Evaluation of carbon stocks in above- and below-ground biomass in Central Africa:
Case study of Lesio-louna tropical rainforest of Congo. Biogeosci. Discuss. 11:10703-10735.

Masripatin N, Ginoga K, Pari G, Dharmawan WS, Siregar CA, Wibowo A, Puspasari D, Utomo AS, Sakuntaladewi N, Lugina M, et al. 2010. Cadangan Karbon pada Berbagai Tipe Hutan dan Jenis Tanaman di Indonesia. Bogor: Pusat Penelitian dan Pengembangan Perubahan Iklim dan Kebijakan.

Nave LE, Domke GM, Hofmeister KL, Mishra U, Perry CH, Walters BF, Swanston CW, 2018. Reforestation can sequester two petagrams of carbon in US topsoils in a century. Proc. Natl. Acad. Sci. 115(11):27762781. https://doi.org/10.1073/pnas.1719685115.

Oktavianto B, Wasis B, Budi SWR. 2015. Pendugaan kandungan biomassa dan karbon atas tanah pada tegakan pinus di lahan pasca tambang silica holcim educational forest. J. Siltrop 3(6):184-189.

Olorunfemi IE, Komolafe AA, Fasinmirin JT. 2019. Biomassa carbon stocks of different land use management in the forest vegetation of Nigeria. Acta Oecologica 95(2019):45-56 doi:10.1016/j.actao.2019.01.004.

Pan Y, Birdsey RA, Fang J, Houghton R, Kauppi PE, Kurz WA, Philips OL, Shvidenko A, Lewis SL, Canadell JG, Ciasis P, et al. 2011. A large and persistent carbon sink in the World's forests. Science 333(6045):988-993. https://doi.org/10.1126/science.1201609.

Pichs-Madruga OR, Sokona Y, Farahani E, Kadner S, Seyboth K, Adler A, Baum I, Brunner S, Eickemeier P, Kriemann B, et al. 2014. Climate Change 2014: Mitigation of Climate Change. Contribution of Working Group III to the Fifth Assessment Report of the Intergovernmental Panel on Climate Change [Edenhofer]. Cambridge dan New York: Cambridge University Press.

Rusolono T, Tiryana T, Purwanto J. 2015. Panduan Survei Cadangan Karbon dan Keanekaragaman Hayati di Sumatera Selatan. Palembang: Biodiversity and Climate Change Project, German International Cooperation-GIZ dan KLHK Dinas Kehutanan Provinsi Sumatera Selatan.

Shunbao L, Yan X, Xiangping F, Yanjie Z. 2019. Soil carbon stock in plantations and natural forest of the sub-tropics. Acta Ecologica Sinica. doi:10.1016/j.chnaes.2019.04.001

Soerianegara I, Indrawan A. 2005. Indonesian forest ecology. Bogor: Fakultas Kehutanan IPB.

Tosiani A. 2015. Buku Kegiatan Serapan dan Emisi Karbon. Sugardima RRA, Rovani R. editor. Jakarta: Kementrian Lingkungan Hidup dan kehutanan.

Urbano AR, Keeton WS. 2017. Carbon dynaics and structural development in recovering secondary forests of the Northeastern U.S. Forest Ecology and Management. 392: 21-35. http://doi.org/f96tpj.

Wasis B. 2012. Soil properties in natural forest destruction and conversion to agricultural land in 
Gunung Leuseur National Park, North Sumatera Province. JMHT. 18(3):206-212.

Watson RT. 2000. Land use, land-use change, and forestry. In: Published for the Intergovernmental Panel on Climate Change. Cambridge: Cambridge University Press.
Watson RT, Noble IR, Bolin B, Ravindranath NH, Verardo DJ, Donken DJ, 2000. Land use, land-use change and forestry. Special Report of the Intergovernmental Panel on Climate Change (IPCC). Cambridge: Cambridge University Press. 